\title{
Adsorption mechanisms of high-levels of ammonium onto natural and NaCl-modified
}

zeolites

Lin Lin ${ }^{\mathrm{a}}$, Zhongfang Lei ${ }^{\mathrm{a}, \mathrm{b},{ }^{*}, \text { Li Wang }^{\mathrm{a}} \text {, Xiang Liu }}$, Yi Zhang ${ }^{\mathrm{a}}$, Chun-Li Wan ${ }^{\mathrm{a}}$, Duu-Jong Lee ${ }^{\mathrm{a}}$, Joo Hwa Tay ${ }^{\mathrm{a}}$

${ }^{a}$ Department of Environmental Science \& Engineering, Fudan University, 220 Handan Road, Shanghai 200433, China

${ }^{\mathrm{b}}$ Graduate School of Life and Environmental Sciences, University of Tsukuba, 1-1-1 Tennoidai, Tsukuba, Ibaraki 305-8572, Japan

*Corresponding author. Present address: Graduate School of Life and Environmental Sciences, University of Tsukuba, 1-1-1 Tennoidai, Tsukuba, Ibaraki 305-8572, Japan.

Email: zflei2005@yahoo.com.cn or lei.zhongfang.gu@u.tsukuba.ac.jp

Phone/Fax: +8129853 6703

\section{Abstract}

Zeolites, microporous aluminosilicate minerals, have high affinity to ammonium in water. This study explored the mechanisms of ammonium adsorption onto natural zeolite and $\mathrm{NaCl}$-modified counterpart under different ammonium levels (10-4000 mg-N/L) and initial $\mathrm{pH}$ 3.4-11.1. Ion exchange dominated the ammonium adsorption process near neutral $\mathrm{pH}$, with the order of exchange selectivity following $\mathrm{Na}^{+}>\mathrm{Ca}^{2+}>\mathrm{K}^{+}>\mathrm{Mg}^{2+}$. At high ammonium levels, $\mathrm{Ca}^{2+}$ exceeded $\mathrm{Na}^{+}$as the dominant ions for ammonium adsorption. Conversely, in strong alkaline solutions, molecular adsorption suppressed ion exchange in ammonium adsorption. $\mathrm{NaCl}$ modification effectively increased ammonium adsorption capacity by increasing the Na contents in zeolite and by modifying the surface morphology to enhance film mass transfer rate. The modified zeolite presents a potential adsorbent to reduce ammonium concentration in landfill leachates, livestock wastewaters or effluents from 
anaerobic digestion tanks of livestock manure.

Keywords: Zeolite; ammonium; ion exchange; molecular adsorption; $\mathrm{NaCl}$ modification

\section{Introduction}

Zeolites are microporous aluminosilicate minerals which could be used as ion exchanger in domestic and commercial water purification, softening and other applications [1]. Substitution of silicon by aluminum atoms in the crystal framework leads to extra negative charge to be balanced by surrounding counterions (such as $\mathrm{Na}^{+}, \mathrm{K}^{+}, \mathrm{Ca}^{2+}, \mathrm{Mg}^{2+}$, etc), and these counterions are easily exchanged by other surrounding cations in a contact solution [2]. Additionally, the high ion exchange capacity (IEC) [3], large reserves of zeolite-rich rock, shortage of competing minerals and the relatively low market price prefer the use of zeolites in large scales.

There are more than 50 species of zeolites, such as clinoptilolite, heulandite, mordenite, erionite, and others[2]. Use of clinoptilolite in industry and academia mainly focuses on its ion exchange properties, especially on its high adsorption capacity and selectivity for ammonium $\left(\mathrm{NH}_{4}{ }^{+}\right)$[4]. Ames [5] noted that the ion exchanging selectivity of clinoptilolite followed $\mathrm{Cs}^{+}>\mathrm{Rb}^{+}>\mathrm{K}^{+}>\mathrm{NH}_{4}^{+}>\mathrm{Ba}^{2+}>\mathrm{Sr}^{2+}>\mathrm{Na}^{+}>\mathrm{Ca}^{2+}>\mathrm{Fe}^{3+}>\mathrm{Al}^{3+}>\mathrm{Mg}^{2+}>\mathrm{Li}^{+}$. Zeolite dosage, particle size, initial ammonium concentration, $\mathrm{pH}$, and temperature could have significant effects on ammonium adsorption capacity [6,7]. Several modification methods have been tried to enhance the ammonium adsorption capacity of zeolite, including microwave pretreatment [8], $\mathrm{NaOH}, \mathrm{HCl}$ or $\mathrm{NaCl}$ solution treatment [9], integrated calcination [10], and others. Equilibrium isotherm and kinetics models of ammonium adsorption onto zeolites were also reported $[11,12]$. Presence of competing cations, like $\mathrm{Na}^{+}$, $\mathrm{K}^{+}, \mathrm{Ca}^{2+}$ and $\mathrm{Mg}^{2+}$, adversely affects ammonium adsorption capacity of zeolites [6].

Zeolites can provide adsorption sites with exchangeable cations for ammonium ion and porosity for free ammonia [13], with ion exchange and molecular adsorption being the main 
mechanisms, respectively. Although the latter is in significant importance especially in practice due to various $\mathrm{pH}$ feeds needed to deal with, few reports could be found on the contribution of molecular adsorption to the whole process. In addition, landfill leachates, livestock wastewater, and effluents from anaerobic digestion tanks of livestock manure could contain ammonium greater than $1000 \mathrm{mg}-\mathrm{N} / \mathrm{L}$ [14-16]. However, current studies on ammonium adsorption onto zeolite are usually conducted at low ammonium levels $(<1000$ mg-N/L) $[6-8,17]$.

The objective of this study was to investigate the mechanisms for ammonium adsorption onto zeolite at ammonium concentration of 10-4000 mg-N/L. Contributions of ion exchange and molecular adsorption mechanisms during ammonium adsorption onto zeolite were clarified. Effects of ammonium concentration and solution $\mathrm{pH}$ (3.4-11.1) on adsorption behavior were discussed. Accordingly, we identified the rate-limiting steps for adsorption kinetics on natural and modified zeolites. To be specific, the term ammonium is the sum of free ammonia $\left(\mathrm{NH}_{3}\right)$ and ionized ammonium $\left(\mathrm{NH}_{4}{ }^{+}\right)$.

\section{Materials and methods}

\subsection{Materials}

Two kinds of zeolites were used in this study. One is natural zeolite which was obtained from Shenshi Mine located in Jinyun, Zhejiang Province, China, and was prepared through crushing, sieving $(1.43-0.80 \mathrm{~mm})$, washing with deionized water and air-drying at $105 \pm 1^{\circ} \mathrm{C}$ for 6 hours. Another is modified zeolite which was obtained by immersing $5 \mathrm{~g}$ of natural zeolite in the flask containing $100 \mathrm{~mL}$ of $2 \mathrm{~mol} / \mathrm{L}$ sodium chloride $(\mathrm{NaCl})$ solution under $35 \pm 1^{\circ} \mathrm{C}$ and $100 \mathrm{rpm}$ in a thermostatic shaker (HZQ-X3000, China) for 24 hours, and then washed with deionized water for three times and dried at $105 \pm 1{ }^{\circ} \mathrm{C}$ for 6 hours.

The feed solutions were prepared by diluting $4000 \mathrm{mg}-\mathrm{N} / \mathrm{L}$ of ammonium chloride $\left(\mathrm{NH}_{4} \mathrm{Cl}\right)$ stock solution with deionized water. All chemicals were of analytical grade, and deionized 
water was used throughout the experiments.

\subsection{Experimental methods}

For each batch adsorption experiment, $2 \mathrm{~g}$ of zeolite was firstly added into the flask containing $100 \mathrm{~mL}$ of a prescribed initial concentration of $\mathrm{NH}_{4}{ }^{+}$solution at desired $\mathrm{pH}$ level (adjusted using $0.1 \mathrm{~mol} / \mathrm{L} \mathrm{HCl}$ or $\mathrm{NaOH}$ solution). Then the flask was shaken at specified agitation speed and temperature controlled in the thermostatic shaker (HZQ-X3000, China). The suspension was finally filtered via $0.45 \mu \mathrm{m}$ filter and the filtrate was analyzed for the target compound(s).

The agitation speed, temperature, initial ammonium concentration, $\mathrm{pH}$, and contact time were the operational parameters investigated in this test. Table 1 lists the detailed conditions for each experiment.

The adsorption performance was evaluated by the amount of ammonium absorbed on per unit mass of zeolite ( $q$ in $\mathrm{mg}-\mathrm{N} / \mathrm{g}$ ), which could be calculated according to Eq. (1).

$$
\mathrm{q}=\left(\mathrm{C}_{0}-\mathrm{C}_{\mathrm{e}}\right) \mathrm{V} / \mathrm{m}
$$

where $\mathrm{C}_{o}$ and $\mathrm{C}_{e}$ are the initial and equilibrium ammonium concentrations (mg-N/L), respectively. $\mathrm{V}$ is the ammonium solution volume (L) and $\mathrm{m}$ is the mass of zeolite used ( $\mathrm{g}$ ).

\subsection{Analytical methods}

Identification of mineral species of the zeolites was carried out by X-ray diffraction (XRD, Bruker-D8 Advance, USA) of the random-oriented powder samples. Energy disperses X-ray spectroscopy (EDS, EDAX-TEAM ${ }^{\mathrm{TM}}$ EDS, USA) was used to determine the chemical composition of samples. The surface morphology of the zeolites was observed by scanning electron microscope (SEM, Philips-XL30 Electron Microscope, Netherland). The BET specific surface area, pore volume and diameter of zeolite samples were determined at $\mathrm{P} / \mathrm{P}_{0}$ $\geq 0.995$ by nitrogen gas adsorption analyzer (Micromeretics-Tristar 3000, USA).

The concentrations of $\mathrm{Na}^{+}, \mathrm{K}^{+}, \mathrm{Ca}^{2+}$ and $\mathrm{Mg}^{2+}$ in solution were measured by atomic 
absorption spectroscopy (AAS, Hitachi-Z 5000, Japan). The concentration of ammonium in solution was determined with the Neslerization method [18]. The solution $\mathrm{pH}$ was determined by a $\mathrm{pH}$ Meter (Hach-HQ11d, USA). All tests were done in duplicate with average data reported.

\section{Results and discussion}

\subsection{Adsorbent characterization}

The XRD patterns of the natural and modified zeolites revealed that the main mineral species in the natural zeolite were clinoptilolite- $\mathrm{Na}$ (formula: $(\mathrm{NaKCa})_{5} \mathrm{Al}_{6} \mathrm{Si}_{30} \mathrm{O}_{72} \cdot 18 \mathrm{H}_{2} \mathrm{O}$ ), heulandite (formula: $\mathrm{Ca}_{3.6} \mathrm{~K}_{0.8} \mathrm{Al}_{8.8} \mathrm{Si}_{27.4} \mathrm{O}_{72} \cdot 26.1 \mathrm{H}_{2} \mathrm{O}$ ) and quartz (formula: $\mathrm{SiO}_{2}$ ) (Fig. 1), accounting for $48 \%, 40 \%$ and $10 \%$, respectively. The intensity changes of XRD peaks for the natural and modified zeolites indicated that the crystal frame structure of zeolite was intact after $\mathrm{NaCl}$ modification. However, the contents of quartz and heulandite seemed decreasing while clinoptilolite- $\mathrm{Na}$ increasing after $\mathrm{NaCl}$ modification. This observation may be a consequence of cation exchange $\left(\mathrm{K}^{+}, \mathrm{Ca}^{2+}\right.$ and $\left.\mathrm{Mg}^{2+}\right)$ with $\mathrm{Na}^{+}$, correlating with the EDS results (Table 2). In particular, the $\mathrm{Na}$ content increased by $192 \%$, while $\mathrm{Ca}, \mathrm{Mg}$ and $\mathrm{K}$ contents decreased by $78 \%, 60 \%$ and $26 \%$ respectively after $\mathrm{NaCl}$ modification.

Besides, the surface of modified zeolite became rougher and more irregular compared with the original zeolite (Figs. 2(a) and 2(b)). And the BET surface area, total pore volume, and average pore diameter of zeolite were significantly increased after $\mathrm{NaCl}$ modification (Table 3). The results indicate that $\mathrm{NaCl}$ immersion is an effective means to modify the surface of present zeolite samples.

\subsection{Effects of agitation speed and temperature}

Agitation speed had no noticeable effects on ammonium adsorption capacity after 24 hours testing, but it had great impact on adsorption kinetics, especially during the initial 120 min of testing (Fig. 3(a)). Specifically, the ammonium adsorption rate increased from 0.049 
$\mathrm{mg}-\mathrm{N} /(\mathrm{g} \cdot \mathrm{min})$ to $0.066 \mathrm{mg}-\mathrm{N} /(\mathrm{g} \cdot \mathrm{min})$ when agitation speed was increased from 0 to $100 \mathrm{rpm}$ with the increasing trend leveled off at higher agitation speeds. Restated, the external mass transfer resistance from bulk solution to zeolite surface was diminished at $>100 \mathrm{rpm}$ agitation speed [7]. This observation indicated that the adsorption was not equilibrated with ion transfer rates at external boundary layers, and the role of surface reaction dominated the process. The results were in accordance with the findings of Erdogan and Ulku [7] and Alkan, et al. [19].

Figure 3(b) showed the effect of temperature on ammonium adsorption by natural zeolite. It seemed that the equilibrium adsorption capacity was not distinctively improved by increasing temperature from 25 to $45^{\circ} \mathrm{C}$. Probably during this process the effective adsorption sites on the zeolite remained unchanged, although ammonium diffusion process may be promoted under higher temperature conditions in which ammonium moves more quickly in solution[19], water viscosity decreases [20], and adsorption sites on the zeolite become more energetic.

Based on the above results, the following experiments were carried out under the condition of $100 \mathrm{rpm}$ and $35^{\circ} \mathrm{C}$.

\subsection{Mechanisms of ammonium adsorption onto zeolite}

\subsubsection{Adsorption isotherm}

Adsorption isotherms can be used to reveal how ammonium ions interact with zeolite surfaces [21]. Langmuir isotherm is applied in this study to describe the monolayer adsorption onto the surface of adsorbent, assuming that the number of energetic adsorption sites are homogeneous and can be saturated [11]:

$$
\mathrm{q}=\mathrm{q}_{\max } \mathrm{K}_{\mathrm{L}} \mathrm{C}_{\mathrm{e}} /\left(1+\mathrm{K}_{\mathrm{L}} \mathrm{C}_{\mathrm{e}}\right)
$$

where $\mathrm{q}_{\max }(\mathrm{mg}-\mathrm{N} / \mathrm{L})$ and $\mathrm{K}_{\mathrm{L}}(\mathrm{L} / \mathrm{mg})$ are the maximum ammonium adsorption capacity and the equilibrium constant, respectively. $\mathrm{C}_{\mathrm{e}}(\mathrm{mg}-\mathrm{N} / \mathrm{L})$ and $\mathrm{q}(\mathrm{mg}-\mathrm{N} / \mathrm{g})$ represent the ammonium concentration in the solution and ammonium adsorption capacity at equilibrium, respectively. 
The linearisation of Eq. (2) is given by Eq. (3)

$$
\mathrm{C}_{\mathrm{e}} / \mathrm{q}=1 /\left(\mathrm{K}_{\mathrm{L}} \mathrm{q}_{\max }\right)+\mathrm{C}_{\mathrm{e}} / \mathrm{q}_{\max }
$$

The Freundlich isotherm assumes that the adsorbent has a heterogeneous surface with non-uniform distribution of adsorption sites. Freundlich parameters can be determined by Eq.

(4) [11]

$$
\mathrm{q}=\mathrm{K}_{\mathrm{F}} \mathrm{C}_{\mathrm{e}}^{1 / \mathrm{n}}
$$

where $K_{F}$ and $1 / n$ represent the Freundlich capacity coefficient and the Freundlich intensity parameter, respectively. The linearisation of Eq. (4) is Eq. (5)

$$
\log \mathrm{q}=\log \mathrm{K}_{\mathrm{F}}+1 / \mathrm{n} \log \mathrm{C}_{\mathrm{e}}
$$

The parameters for the Langmuir and Freundlich isotherms were evaluated based on the data from present experimental ammonium-zeolite systems (Table 4), with the Langmuir fitting the data better than the Freundlich. This implies that ammonium adsorption onto the natural zeolite is more like a monolayer adsorption process with uniform distribution of energetic adsorption sites on its surface. The maximum adsorption capacity of the natural zeolite was estimated $14.3 \mathrm{mg}-\mathrm{N} / \mathrm{g}$, slightly higher than those of Yusof et al. [22] (11.3 mg-N/g for granulated natural Indonesian mordenite), of Karadag et al. [17] (6.32 mg-N/g for Turkish clinoptilolite), and of Widiastuti et al. [12] (3.89 mg-N/g for Australian natural zeolite).

\subsubsection{Ion exchange}

According to the fundamental of ion exchange between solid and liquid phases [23], the ion exchange process between zeolite frame and aqueous ammonium solution can be expressed by Eq. (6)

$$
\mathrm{Ze}-\mathrm{M}^{\mathrm{n}+}+\mathrm{nNH}_{4}{ }^{+} \longleftrightarrow \mathrm{Ze}-\mathrm{nNH}_{4}{ }^{+}+\mathrm{M}^{\mathrm{n}+}
$$

where Ze and M represent zeolite and the loosely held cations in zeolite, respectively, and $\mathrm{n}$ is the number of electric charge.

Assuming that the exchangeable cations in zeolites are $\mathrm{Ca}^{2+}, \mathrm{Na}^{+}, \mathrm{K}^{+}$and $\mathrm{Mg}^{2+}$ [24], the 
ion exchange capacity (IEC) is defined as the sum of exchanged cations as follows:

$$
\mathrm{IEC}=\left[\mathrm{Na}^{+}\right]+\left[\mathrm{K}^{+}\right]+2\left[\mathrm{Ca}^{2+}\right]+2\left[\mathrm{Mg}^{2+}\right]=\left[\mathrm{NH}_{4}^{+}\right]
$$

Figure 4 shows the variation of equivalent concentrations of $\mathrm{Ca}^{2+}, \mathrm{Na}^{+}, \mathrm{K}^{+}$, and $\mathrm{Mg}^{2+}$ released into solution under different initial ammonium concentrations. The sum of these four cations (IEC) was almost equal to the ammonium adsorption capacity at equilibrium $(q)$, demonstrating the predominant role of ion exchange in ammonium adsorption to zeolite. The maximum IEC was $0.92 \mathrm{meq} / \mathrm{g}$, lower than the theoretical ion exchange capacity (TIEC) [24], $2.86 \mathrm{meq} / \mathrm{g}$ from chemical composition of natural zeolite if all alkaline and alkaline-earth cations in zeolite were replaced. Restated, about $32 \%$ of the exchangeable sites were available for ammonium adsorption, probably owing to limited access of ammonium ions to interior sites of zeolites.

From Fig. 4, the order of ammonium ion exchange selectivity for cations on the natural zeolite was determined as $\mathrm{Na}^{+}>\mathrm{Ca}^{2+}>\mathrm{K}^{+}>\mathrm{Mg}^{2+}$, slightly different from results of Watanabe et al. [25] $\left(\mathrm{Na}^{+}>>\mathrm{K}^{+}>\mathrm{Ca}^{2+}>\mathrm{Mg}^{2+}\right)$. This inconsistency is attributed to the difference in chemical compositions of tested zeolites: rather low Ca content in their chosen zeolite. $\mathrm{Na}^{+}$ was the dominant cation exchanged with ammonium under lower initial ammonium concentration conditions (less than 500mg-N/L) (Fig. 4). With the increase of initial ammonium concentration $\mathrm{Ca}^{2+}$ started to dominate the ion exchange process after most $\mathrm{Na}$ being released, especially at higher initial ammonium concentrations (> $1000 \mathrm{mg}-\mathrm{N} / \mathrm{L}$ ). Conversely, $\mathrm{K}^{+}$is preferred than $\mathrm{NH}_{4}{ }^{+}$in ion exchange sequence for clinoptilolite [[5]. In the present tests the $\mathrm{K}^{+}$was low in concentration and was slightly increased with initial ammonium concentration. Owing to the strong affinity of $\mathrm{K}^{+}$with zeolite, $\mathrm{K}^{+}$released by ammonium adsorption might be re-adsorbed back to zeolite via exchange with $\mathrm{Na}^{+}, \mathrm{Ca}^{2+}$ or $\mathrm{Mg}^{2+}$. After most available sites were covered by ammonium ions, the released $\mathrm{K}^{+}$could not be easily re-adsorbed back so its concentration was increased in solution. The low content in zeolite and high hydrated radius in solution hindered the exchange of $\mathrm{Mg}^{2+}$ with ammonium ions [26]. 
The ion exchange mechanism of ammonium adsorption could be confirmed by comparing chemical composition changes of natural zeolite before and after adsorption (Table 2). Clearly at $1000 \mathrm{mg}-\mathrm{N} / \mathrm{L}$ of ammonium the contents of $\mathrm{Na}, \mathrm{Ca}, \mathrm{K}$, and $\mathrm{Mg}$ of the natural zeolite decreased after reaching the equilibrium of ammonium adsorption.

\subsubsection{Molecular adsorption}

Ammonium in the bulk solution exists in both ionized and molecular forms. $\mathrm{pH}$ and temperature affect the forms of ammonium in solution [27]. The relationship between $\mathrm{pH}$, temperature $(\mathrm{T})$, ionized ammonium $\left(\mathrm{NH}_{4}{ }^{+} \mathrm{N}\right)$, free ammonia $\left(\mathrm{NH}_{3}-\mathrm{N}\right)$ and total ammonium (TAN) can be expressed by Eqs. (8)-(10) [27]

$$
\begin{aligned}
& {\left[\mathrm{NH}_{3}-\mathrm{N}\right](\mathrm{mg} / \mathrm{L}) /[\mathrm{TAN}](\mathrm{mg} / \mathrm{L})=10^{\mathrm{pH}} /\left(10^{\mathrm{pH}}+\mathrm{e}^{6344(273+\mathrm{T})}\right)} \\
& {\left[\mathrm{NH}_{4}{ }^{+}-\mathrm{N}\right](\mathrm{mg} / \mathrm{L}) /[\mathrm{TAN}](\mathrm{mg} / \mathrm{L})=\mathrm{e}^{6344(273+\mathrm{T})} /\left(10^{\mathrm{pH}}+\mathrm{e}^{6344(273+\mathrm{T})}\right)} \\
& {[\mathrm{TAN}]=\left[\mathrm{NH}_{3}-\mathrm{N}\right]+\left[\mathrm{NH}_{4}{ }^{+}-\mathrm{N}\right]}
\end{aligned}
$$

The distributions of the free and ionized forms of ammonium were calculated based on Eqs. (8)-(10) at $100 \mathrm{mg}-\mathrm{N} / \mathrm{L}$ and $1000 \mathrm{mg}-\mathrm{N} / \mathrm{L}$ of initial ammonium concentrations $\left(35^{\circ} \mathrm{C}\right)$. When $\mathrm{pH}<7$, more than $95 \%$ of the ammonium existed in ionized form $\left(\mathrm{NH}_{4}^{+}\right)$; when $\mathrm{pH}$ approached 11 , only about $1 \%$ of ammonium was left in ionized form(data not shown).

Figure 5 depicts that the ammonium adsorption onto natural zeolite is a $\mathrm{pH}$-dependent process. The maximum ammonium removal occurred at $\mathrm{pH} 6.4$ or 6.5 , about $82.3 \mathrm{mg}-\mathrm{N} / \mathrm{L}$ and $215.8 \mathrm{mg}-\mathrm{N} / \mathrm{L}$ for $100 \mathrm{mg}-\mathrm{N} / \mathrm{L}$ and $1000 \mathrm{mg}-\mathrm{N} / \mathrm{L}$ of initial ammonium concentrations, respectively. The ammonium removal decreased slightly with decreasing $\mathrm{pH}$, principally being attributed to the increase in competing hydrogen ions. The increase in $\mathrm{pH}$ reduced ammonium removal, especially at $\mathrm{pH}>9$, likely owing to the fewer ammonium ions presented in alkaline solutions. This observation correlates with the findings by Huang et al.[6] and Erdogan and Ulku[7]. 
The increase in ammonia removal at increased $\mathrm{pH}$ and initial ammonia concentration suggests the interplay of molecular adsorption mechanism. The significance of molecular adsorption was negligible at $\mathrm{pH}<8$. At $\mathrm{pH} 9.5,45 \%$ and $8.5 \%$ of ammonium removal were contributed by free ammonia adsorption under $100 \mathrm{mg}-\mathrm{N} / \mathrm{L}$ and $1000 \mathrm{mg}-\mathrm{N} / \mathrm{L}$, respectively (Figs. 5(a) and 5(b)). At pH 11.1, molecular adsorption was the dominant mechanism owing to the absence of ionized ammonium in solution (Fig. 5). Anyway, the molecular adsorption was of secondary importance and contributed less to the total ammonium removal according to the experimental results under neutral $\mathrm{pH}$ conditions.

\subsection{Kinetic analysis}

Figure 6 illustrates the kinetic data for natural and modified zeolites at $1000 \mathrm{mg}-\mathrm{N} / \mathrm{L}$ of initial ammonium concentration. Ammonium adsorption on zeolite proceeded fast, particularly during the initial 100 min of testing, which might be a result of vacant adsorption sites on the zeolites [28]. The equilibrium could be reached in 12 hours (Fig. 6(a)).

Compared with the natural zeolite, the modified zeolite exhibited 58\% higher in ammonium adsorption capacity and at faster adsorption rate, especially during the first $15 \mathrm{~min}$ of adsorption. This observation is attributable to the higher Na ions for modified zeolite than the original zeolite, and the absorbed $\mathrm{Na}^{+}$ions were readily exchanged by ammonium ions on zeolite surfaces. This statement was manifested by the result from AAS analysis showing that about $95 \%$ of IEC was $\mathrm{Na}^{+}$under $1000 \mathrm{mg}-\mathrm{N} / \mathrm{L}$ of ammonium for modified zeolite (data not shown). Additionally, $\mathrm{NaCl}$ modification replaced $\mathrm{Ca}$ and $\mathrm{Mg}$ on zeolite resulting in producing large pores and cavities in the zeolite (Table 3 and Fig. 2). So the modified zeolite could have superior adsorption performance than the original zeolite.

Intra-particle diffusion model can be adopted to identify the diffusion mechanism of ammonium adsorption process [29] 


$$
\mathrm{q}_{\mathrm{t}}=\mathrm{k}_{\mathrm{d}} \mathrm{t}^{1 / 2}+\mathrm{C}
$$

where $k_{d}$ is the coefficient of intra-particle diffusion $\left(\mathrm{mg} /\left(\mathrm{g} \cdot \mathrm{min}^{1 / 2}\right)\right)$.

Figure 6(b) depicts that the intra-particle diffusion model fitted well the experimental data if the whole adsorption process was divided into two linear regions. Hence, the ammonium adsorption process might be described by film diffusion followed by intra-particle diffusion process[30]. The contribution of each rate controlling step in the ammonium adsorption onto zeolite was further analyzed by calculating the film diffusion $\left(D_{f}\right)$ and particle diffusion $\left(D_{p}\right)$ coefficients according to the corresponding models given below[20,23]:

Film diffusion model:

$$
\ln \left(1-\mathrm{q}_{\mathrm{t}} / \mathrm{q}_{\mathrm{e}}\right)=-\mathrm{k}_{\mathrm{f}} \mathrm{t}
$$

Particle diffusion model:

$$
\ln \left[1-\left(\mathrm{q}_{\mathrm{t}} / \mathrm{q}_{\mathrm{e}}\right)^{2}\right]=-2 \mathrm{k}_{\mathrm{p}} \mathrm{t}
$$

where $\mathrm{k}_{\mathrm{f}}=\mathrm{D}_{\mathrm{f}} \mathrm{C}_{\mathrm{s}} / \mathrm{C}_{\mathrm{z}}$ hr and $\mathrm{k}_{\mathrm{p}}=\mathrm{D}_{\mathrm{p}} \pi^{2} / \mathrm{r}^{2}$ are the rate constants. $\mathrm{C}_{\mathrm{S}}$ and $\mathrm{C}_{\mathrm{z}}(\mathrm{mg} / \mathrm{kg})$ are the concentrations of ammonium in solution and zeolite, respectively; $r$ is the average radius of zeolite particles (averagely $5 \times 10^{-4} \mathrm{~m}$ in this study), $\mathrm{t}$ is the contact time (min); and $\mathrm{h}$ is the thickness of film around the zeolite particle $\left(10^{-5} \mathrm{~m}\right.$ for poorly stirred solution [20]).

The best-fit $D_{f}$ and $D_{p}$ values for ammonia adsorption onto the natural and modified zeolites are listed in Table 5 . The $\mathrm{D}_{\mathrm{p}}$ values for both zeolites were considerably lower than those of $\mathrm{D}_{\mathrm{f}}$, indicating that particle diffusion was the rate-limiting step for ammonium adsorption and the ammonium adsorption was mainly occurred at the surface of zeolite with monolayer molecular adsorption. Similar results were reported by mordenite tests [31] and natural Iranian zeolite [20] at low initial ammonium concentrations. Compared with the natural zeolite, the $D_{f}$ and $D_{p}$ values of the modified zeolite increased by $185 \%$ and $2.3 \%$, respectively, indicating that $\mathrm{NaCl}$ modification could reduce the resistance for mass transfer in film diffusion but have little effects on intra-particle diffusion. Namely, $\mathrm{NaCl}$ modification could effectively improve the surface morphology of zeolite particles, but hardly alter the intra-particle structures. 


\section{Conclusions}

In conclusion, this study discloses the mechanisms of ammonium adsorption onto zeolites at different initial ammonium concentrations (10-4000 mg-N/L) and $\mathrm{pH}$ levels (3.4-11.1). The ion exchange mechanism dominated the ammonium adsorption process with the order of exchange selectivity for cations: $\mathrm{Na}^{+}>\mathrm{Ca}^{2+}>\mathrm{K}^{+}>\mathrm{Mg}^{2+}$. At initial ammonium concentration $>1000 \mathrm{mg}-\mathrm{N} / \mathrm{L}, \mathrm{Ca}^{2+}$ exceeded $\mathrm{Na}^{+}$to dominate the ion exchange process owing to depletion of $\mathrm{Na}$ in zeolite. Molecular adsorption occurred at alkaline conditions. $\mathrm{NaCl}$ modification enhanced ammonium adsorption capacity from 11.0 to $17.3 \mathrm{mg}-\mathrm{N} / \mathrm{g}$ (Fig. 6(a)), mainly being contributed by the increased $\mathrm{Na}$ contents in zeolite $(192 \%)$, and by the increased specific surface $(32 \%)$ and pore diameter $(80 \%)$ of zeolite, respectively(Table 3). Particle diffusion was the rate-limiting step for the present ammonium adsorption process. The $\mathrm{NaCl}$ modification can promote film diffusion significantly through improving the surface characteristics of zeolite.

\section{References:}

[1] P.A. Singer, F. Salamanca-Buentello, A.S. Daar, Harnessing Nanotechnology to Improve Global Equity, Issues Sci. Technol. 21 (2005) 57-64.

[2] G.V. Tsitsishvili, T.G. Andronikashvili, G.N. Kirov, L.D. Filizova, Natural zeolites, Ellis Horwood New York, 1992.

[3] M. Kithome, J.W. Paul, L.M. Lavkulich, A.A. Bomke, Kinetics of ammonium adsorption and desorption by the natural zeolite clinoptilolite, Soil Sci. Soc. Am. J. 62 (1998) $622-629$.

[4] K. Metropoulos, E. Maliou, M. Loizidou, N. Spyrellis, Comparative-studies between 
synthetic and natural zeolites ammonium uptake, J. Environ. Sci. Health, Part A: Toxic/Hazard. Subst. Environ. Eng. 28 (1993) 1507-1518.

[5] L.L. Ames, The cation sieve properties of clinoptilolite, Am. Mineral. 45 (1960) 689-700.

[6] H.M. Huang, X.M. Xiao, B. Yan, L.P. Yang, Ammonium removal from aqueous solutions by using natural Chinese (Chende) zeolite as adsorbent, J. Hazard. Mater. 175 (2010) 247-252.

[7] B.C. Erdogan, S. Ulku, Ammonium sorption by Gordes clinoptilolite rich mineral specimen, Appl. Clay Sci. 54 (2011) 217-225.

[8] L.C. Lei, X.J. Li, X.W. Zhang, Ammonium removal from aqueous solutions using microwave-treated natural Chinese zeolite, Sep. Purif. Technol. 58 (2008) 359-366.

[9] H.B. Wang, Y.M. Bao, J. Zhang, H.Y. Chen, L.Z. Ma, M. Yang, Study on the Preparation and Properties of Na-modified Zeolites, Energy Procedia 11 (2011) $4236-4241$.

[10] Z. Liang, J.R. Ni, Improving the ammonium ion uptake onto natural zeolite by using an integrated modification process, J. Hazard. Mater. 166 (2009) 52-60.

[11] S. Balci, Nature of ammonium ion adsorption by sepiolite: analysis of equilibrium data with several isotherms, Water Res. 38 (2004) 1129-1138.

[12] N. Widiastuti, H.W. Wu, H.M. Ang, D.K. Zhang, Removal of ammonium from greywater using natural zeolite, Desalination 277 (2011) 15-23.

[13] S. Ioannidis, A. Anderko, Equilibrium modeling of combined ion-exchange and 
molecular adsorption phenomena, Ind. Eng. Chem. Res. 40 (2001) 714-720.

[14] R. Ganigue, H. Lopez, M.D. Balaguer, J. Colprim, Partial ammonium oxidation to nitrite of high ammonium content urban land fill leachates, Water Res. 41 (2007) $3317-3326$.

[15] A. Terada, K. Hibiya, J. Nagai, S. Tsuneda, A. Hirata, Nitrogen removal characteristics and biofilm analysis of a membrane-aerated biofilm reactor applicable to high-strength nitrogenous wastewater treatment, J. Biosci. Bioeng. 95 (2003) 170-178.

[16] G. Bujoczek, J. Oleszkiewicz, R. Sparling, S. Cenkowski, High solid anaerobic digestion of chicken manure, J. Agric. Eng. Res. 76 (2000) 51-60.

[17] D. Karadag, Y. Koc, M. Turan, B. Armagan, Removal of ammonium ion from aqueous solution using natural Turkish clinoptilolite, J Hazard. Mater. 136 (2006) 604-609.

[18] APHA, AWWA, WEF, Standard Methods for the Examination of Water \& Wastewater, $21^{\text {st }}$ ed., Washington, DC, 2005.

[19] M. Alkan, M. Dogan, Y. Turhan, O. Demirbas, P. Turan, Adsorption kinetics and mechanism of maxilon blue 5G dye on sepiolite from aqueous solutions, Chem. Eng. J. 139 (2008) 213-223.

[20] G. Moussavi, S. Talebi, M. Farrokhi, R.M. Sabouti, The investigation of mechanism, kinetic and isotherm of ammonia and humic acid co-adsorption onto natural zeolite, Chem. Eng. J. 171 (2011) 1159-1169.

[21] Y.F. Wang, F. Lin, W.Q. Pang, Removal of ammonium ions from wastewater using modified zeolites, Fresen. Environ. Bull. 16 (2007) 24-28. 
[22] A.M. Yusof, L.K. Keat, Z. Ibrahim, Z.A. Majid, N.A. Nizam, Kinetic and equilibrium studies of the removal of ammonium ions from aqueous solution by rice husk ash-synthesized zeolite $\mathrm{Y}$ and powdered and granulated forms of mordenite, J. Hazard. Mater. 174 (2010) 380-385.

[23] F.G. Helfferich, Ion exchange, Dover Pubns, New York, 1995.

[24] V.J. Inglezakis, The concept of "capacity" in zeolite ion-exchange systems, J. Colloid. Interf. Sci. 281 (2005) 68-79.

[25] Y. Watanabe, H. Yamada, H. Kokusen, J. Tanaka, Y. Moriyoshi, Y. Komatsu, Ion exchange behavior of natural zeolites in distilled water, hydrochloric acid, and ammonium chloride solution, Sep. Sci. Technol. 38 (2003) 1519-1532.

[26] N. Kantiranis, K. Sikalidis, A. Godelitsas, C. Squires, G. Papastergios, A. Filippidis, Extra-framework cation release from heulandite-type rich tuffs on exchange with $\mathrm{NH}_{4}{ }^{+}, \mathrm{J}$. Environ. Manage. 92 (2011) 1569-1576.

[27] D.L. Ford, R.L. Churchwell, J.W. Kachtick, Comprehensive analysis of nitrification of chemical processing wastewaters, J. Water Pollut. Control Fed. (1980) 2726-2746.

[28] Q. Du, S.J. Liu, Z.H. Cao, Y.Q. Wang, Ammonia removal from aqueous solution using natural Chinese clinoptilolite, Sep. Purif. Technol. 44 (2005) 229-234.

[29] V. Vadivelan, K.V. Kumar, Equilibrium, kinetics, mechanism, and process design for the sorption of methylene blue onto rice husk, J. Colloid Interf. Sci. 286 (2005) 90-100.

[30] S.J. Allen, G. Mckay, K. Khader, Intraparticle diffusion of a basic dye during adsorption onto sphagnum peat, Environ. Pollut. 56 (1989) 39-50. 
[31] M. Sprynskyy, M. Lebedynets, R. Zbytniewski, J. Namiesnik, B. Buszewski, Ammonium removal from aqueous solution by natural zeolite, Transcarpathian mordenite, kinetics, equilibrium and column tests, Sep. Purif. Technol.46 (2005) 155-160. 


\section{Tables}

Table 1

Experimental conditions for zeolite adsorption.

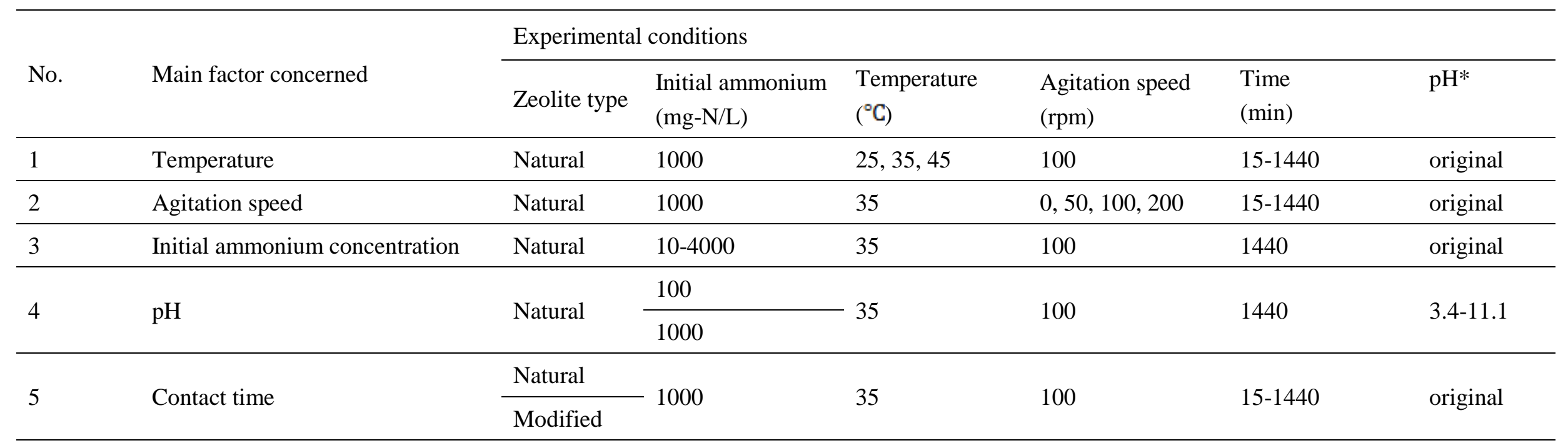

(*The original $\mathrm{pH}$ of 100 and $1000 \mathrm{mg}-\mathrm{N} / \mathrm{L}$ of ammonium chloride solution were 6.68 and 5.38, respectively) 
Table 2

Chemical compositions of the natural and modified zeolites before and after ammonium adsorption under $1000 \mathrm{mg}-\mathrm{N} / \mathrm{L}$ of initial ammonium concentration by EDS (wt\%).

\begin{tabular}{lrrrrr}
\hline \multirow{2}{*}{$\begin{array}{l}\text { Chemical } \\
\text { elements }\end{array}$} & \multicolumn{2}{c}{ Before adsorption } & & \multicolumn{2}{c}{ After adsorption } \\
\cline { 2 - 3 } \cline { 5 - 6 } & Natural & Modified & & Natural & Modified \\
$\mathrm{Na}$ & 42.73 & 40.78 & & 48.69 & 45.98 \\
$\mathrm{Mg}$ & 1.61 & 4.70 & & 0.49 & 0.59 \\
$\mathrm{Al}$ & 0.87 & 0.35 & & 0.35 & 0.38 \\
$\mathrm{Si}$ & 11.00 & 9.63 & & 9.63 & 6.87 \\
$\mathrm{~K}$ & 37.22 & 41.33 & & 38.18 & 43.81 \\
$\mathrm{Ca}$ & 1.52 & 1.48 & & 0.84 & 1.40 \\
Others & 2.09 & 0.45 & & 0.77 & 0.20 \\
\hline
\end{tabular}


Table 3

Information of surface area and pore size for the natural and modified zeolites by BET (at $\left.\mathrm{P} / \mathrm{P}_{0} \geq 0.995\right)$.

\begin{tabular}{lccc}
\hline & Unit & \multicolumn{2}{c}{ Zeolite type } \\
\cline { 3 - 4 } BET surface area & $\mathrm{m}^{2} / \mathrm{g}$ & 14.33 & Natural \\
Total pore volume & $\mathrm{cm}^{3} / \mathrm{g}$ & 0.044 & 0.83 \\
Average pore diameter & $\mathrm{nm}$ & 16.19 & 0.065 \\
& & & 29.24 \\
\hline
\end{tabular}


Table 4

Isotherms constants for ammonium adsorption onto the natural zeolite.

\begin{tabular}{lllllll}
\hline \multicolumn{2}{l}{ Langmuir parameters } & & & \multicolumn{4}{l}{ Freundlich parameters } \\
\cline { 1 - 2 } \cline { 6 - 8 }$q_{\max }(\mathrm{mg}-\mathrm{N} / \mathrm{g})$ & $K_{L}$ & $R^{2}$ & & $K_{F}$ & $1 / n$ & $R^{2}$ \\
\hline 14.265 & 0.009 & 0.993 & & 0.985 & 0.355 & 0.973 \\
\hline
\end{tabular}


Table 5

Kinetic constants for ammonium adsorption onto the natural and modified zeolites.

Zeolite type

Models

Parameters

\begin{tabular}{|c|c|c|c|c|}
\hline & & & Natural & Modified \\
\hline \multirow{4}{*}{$\begin{array}{l}\text { Intra-particle diffusion } \\
\text { model }\end{array}$} & \multirow{2}{*}{ First stage } & $k_{d l}$ & 0.797 & 1.561 \\
\hline & & $\mathrm{R}^{2}$ & 0.984 & 0.916 \\
\hline & \multirow{2}{*}{ Second stage } & $k_{d 2}$ & 0.095 & 0.173 \\
\hline & & $\mathrm{R}^{2}$ & 0.815 & 0.877 \\
\hline \multirow{2}{*}{ Film diffusion model } & & $D_{f}\left(\mathrm{~m}^{2} / \mathrm{s}\right)$ & $8.422 \times 10^{-10}$ & $24.021 \times 10^{-10}$ \\
\hline & & $\mathrm{R}^{2}$ & 0.966 & 0.855 \\
\hline \multirow{2}{*}{ Particle diffusion model } & & $D_{p}\left(\mathrm{~m}^{2} / \mathrm{s}\right)$ & $5.700 \times 10^{-11}$ & $5.832 \times 10^{-11}$ \\
\hline & & $\mathrm{R}^{2}$ & 0.974 & 0.988 \\
\hline
\end{tabular}




\section{Figure captions}

Fig. 1. XRD patterns of the natural and modified zeolites.

Fig. 2. SEM images of the natural (a) and modified zeolites (b).

Fig. 3. Effects of agitation speed and temperature on ammonium adsorption by natural zeolite under $1000 \mathrm{mg}-\mathrm{N} / \mathrm{L}$ of initial ammonium concentration condition. (a) Effect of agitation speed under $35^{\circ} \mathrm{C}$, (b) Effect of temperature under $100 \mathrm{rpm}$.

Fig. 4. The ions release and ammonium adsorption capacity of natural zeolite under different initial ammonium concentration conditions.

Fig. 5. Effect of $\mathrm{pH}$ on ammonium and ammonia removal by natural zeolite under initial ammonium concentration of $100 \mathrm{mg}-\mathrm{N} / \mathrm{L}$ and $1000 \mathrm{mg}-\mathrm{N} / \mathrm{L}$, respectively $\left(35^{\circ} \mathrm{C}\right)$.

Fig. 6. Kinetic results of ammonium adsorption onto the natural and modified zeolites under $1000 \mathrm{mg}-\mathrm{N} / \mathrm{L}$ of initial ammonium concentration condition. (a) Effect of contact time, (b) Kinetic plots of intra-particle diffusion model. 


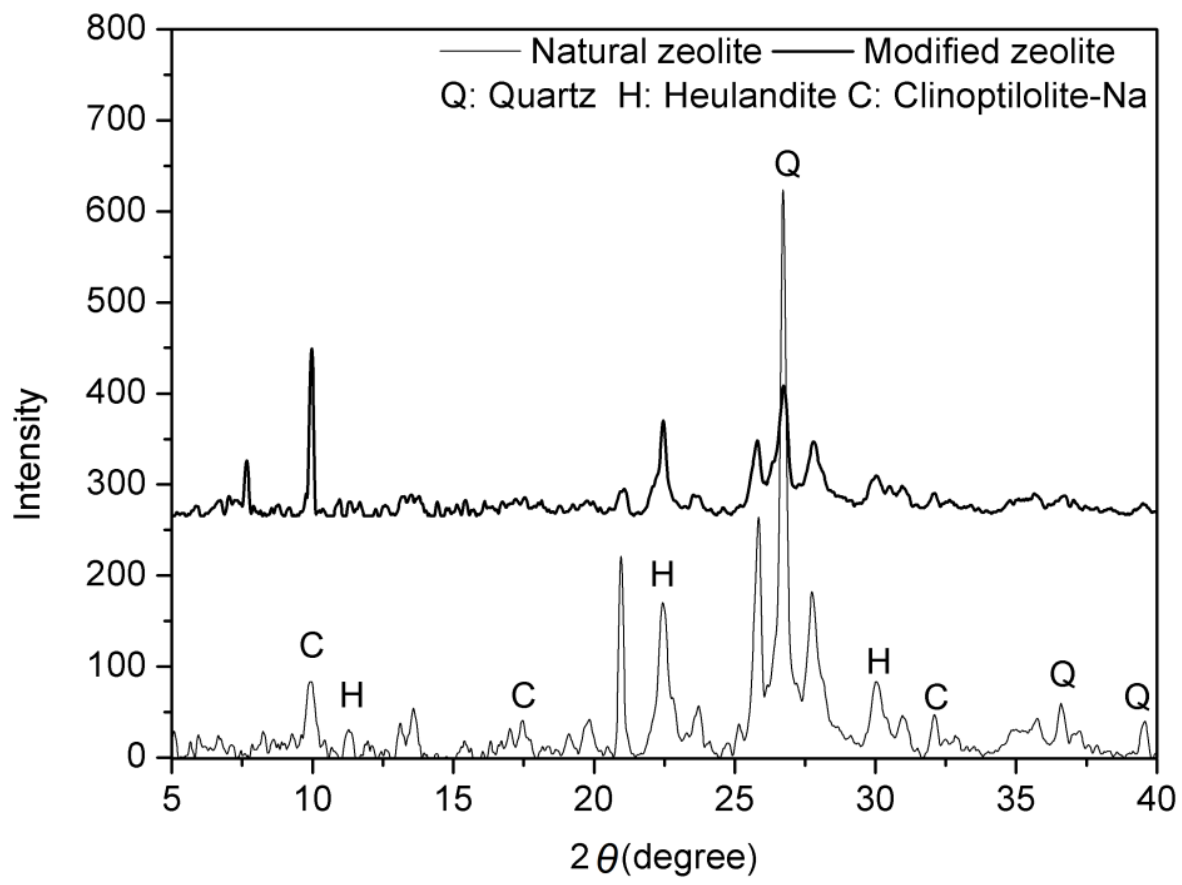

Fig. 1 


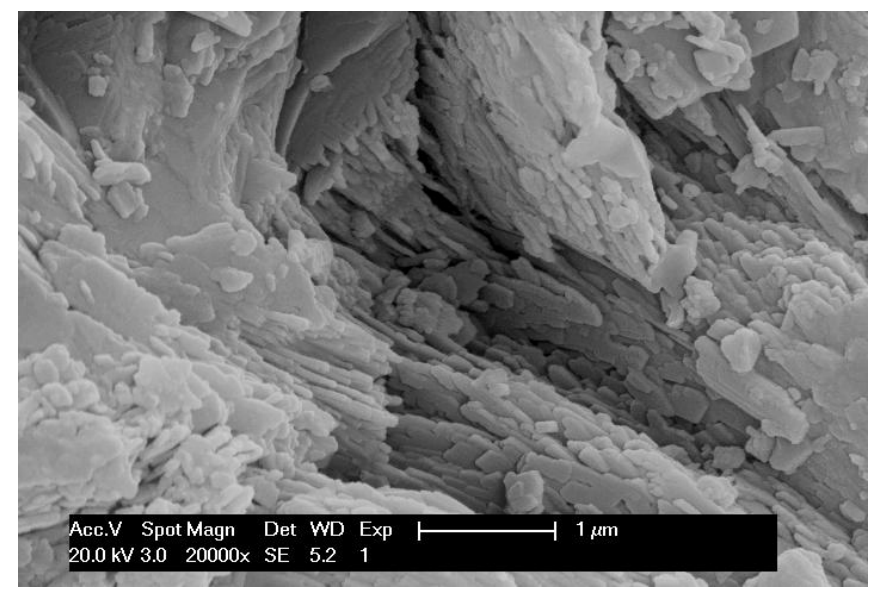

Fig. 2(a)

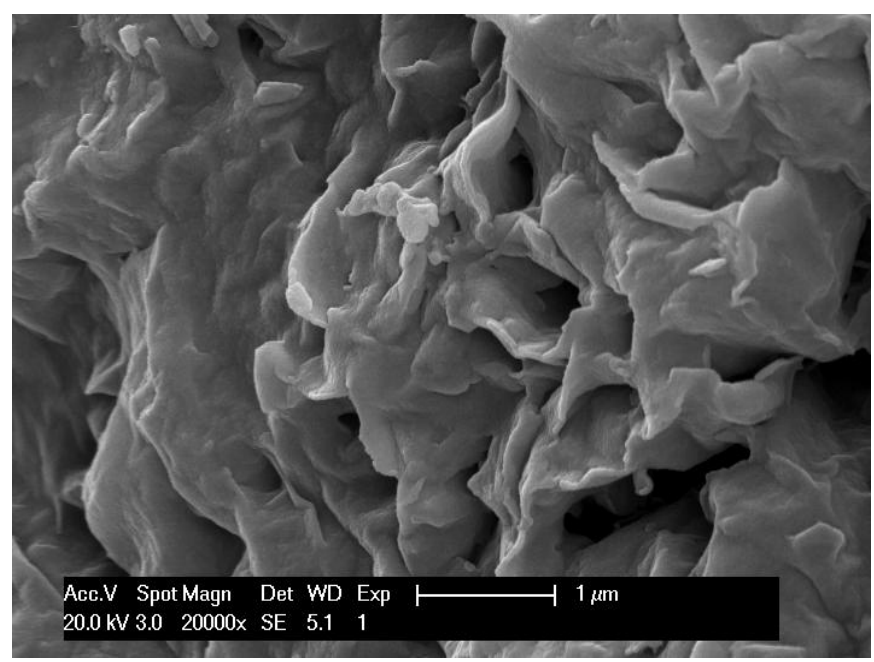

Fig. 2(b) 


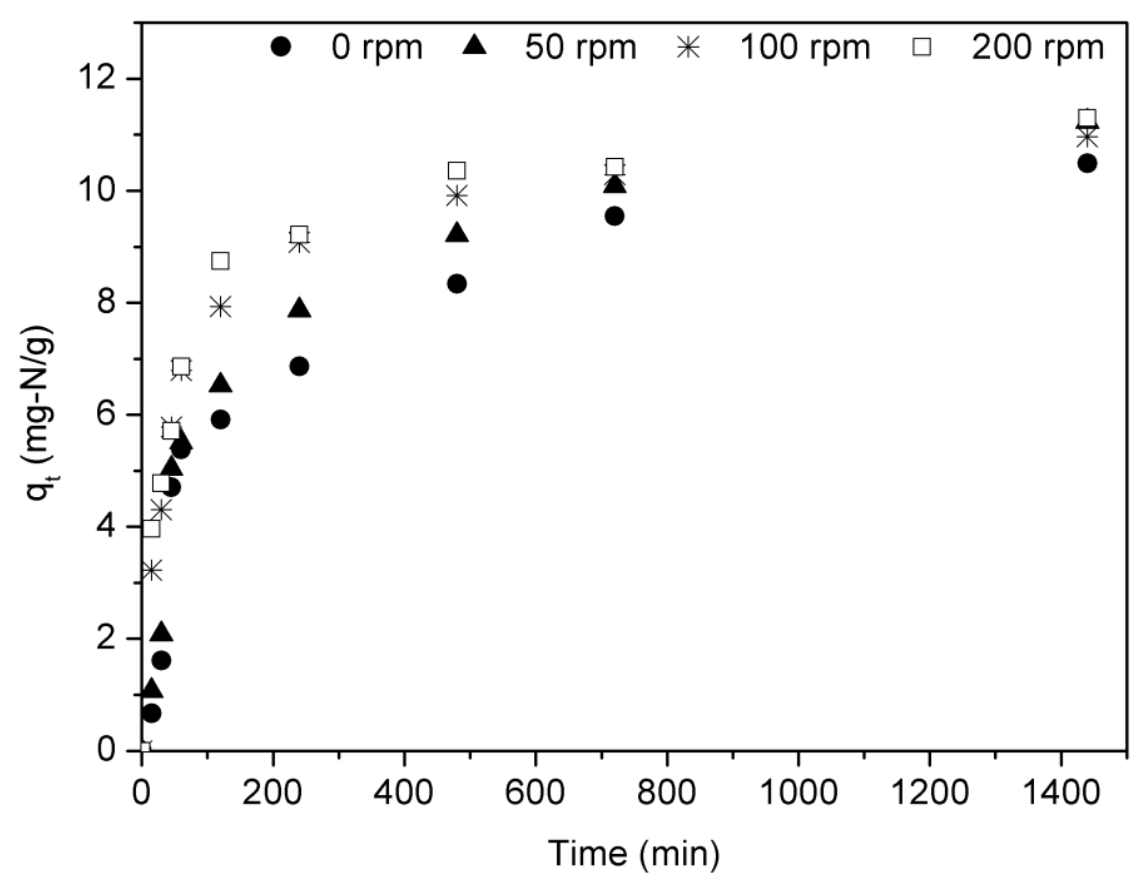

Fig. 3(a)

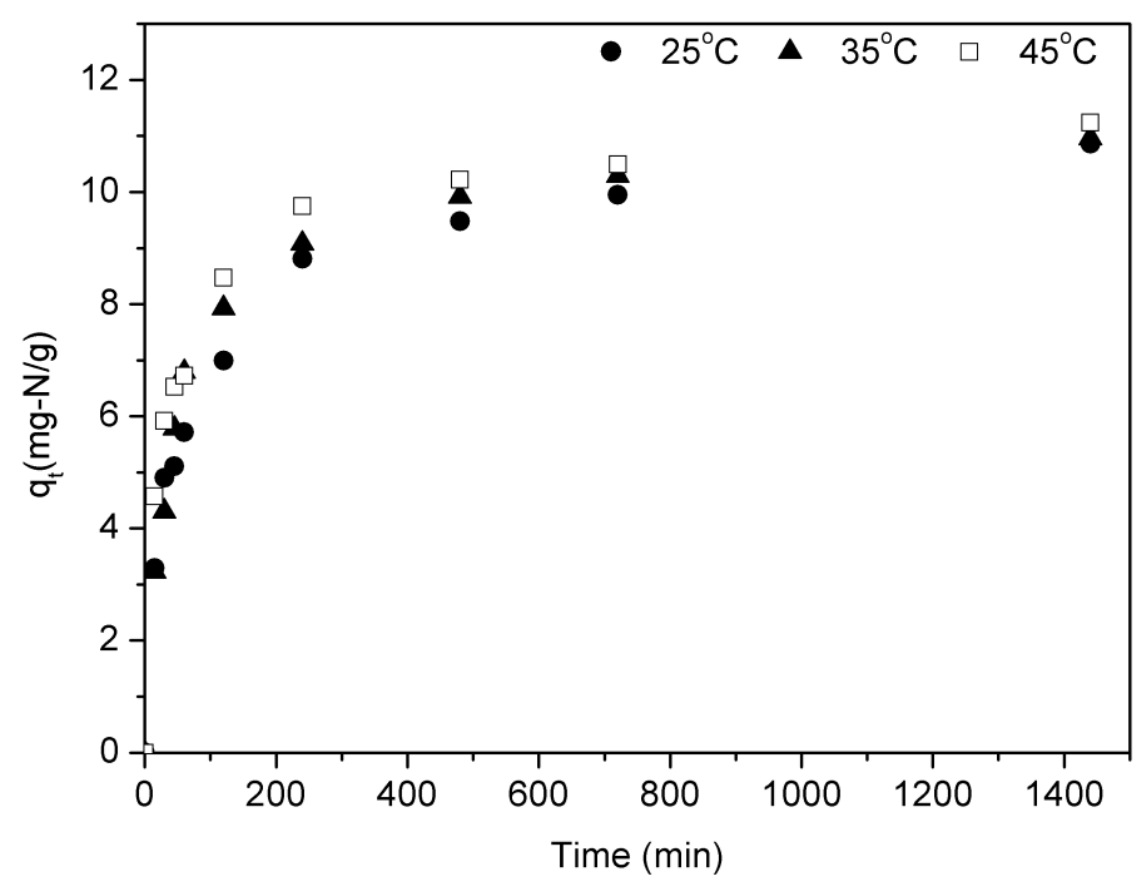

Fig. 3(b) 


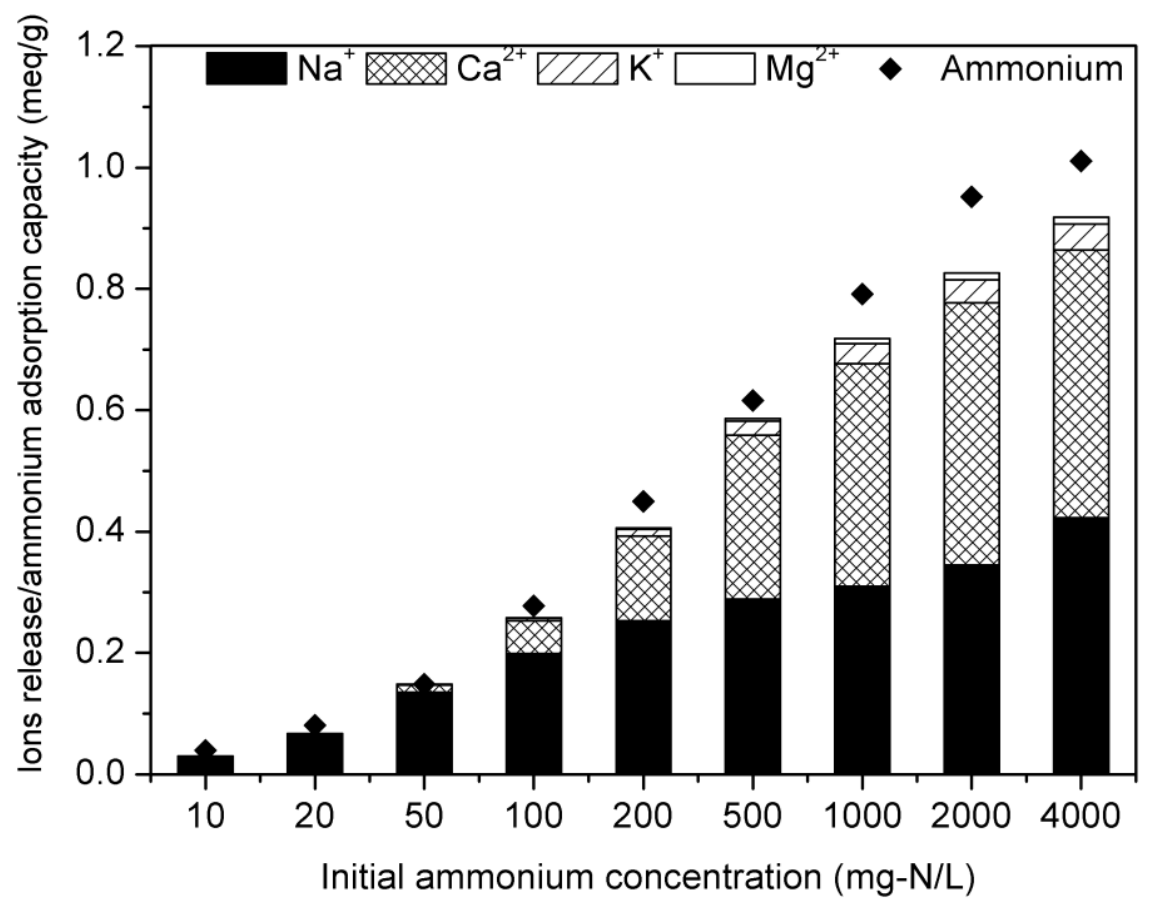

Fig. 4 


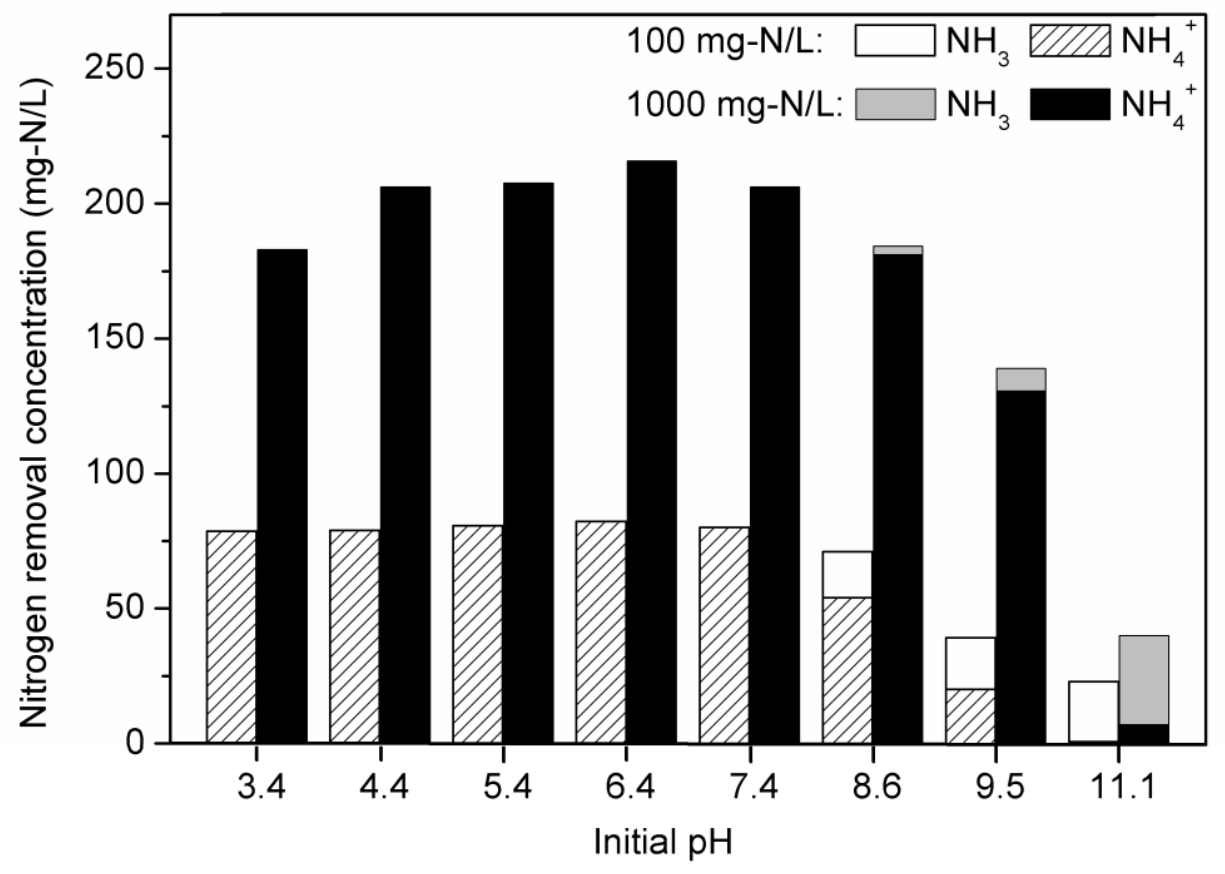

Fig. 5 


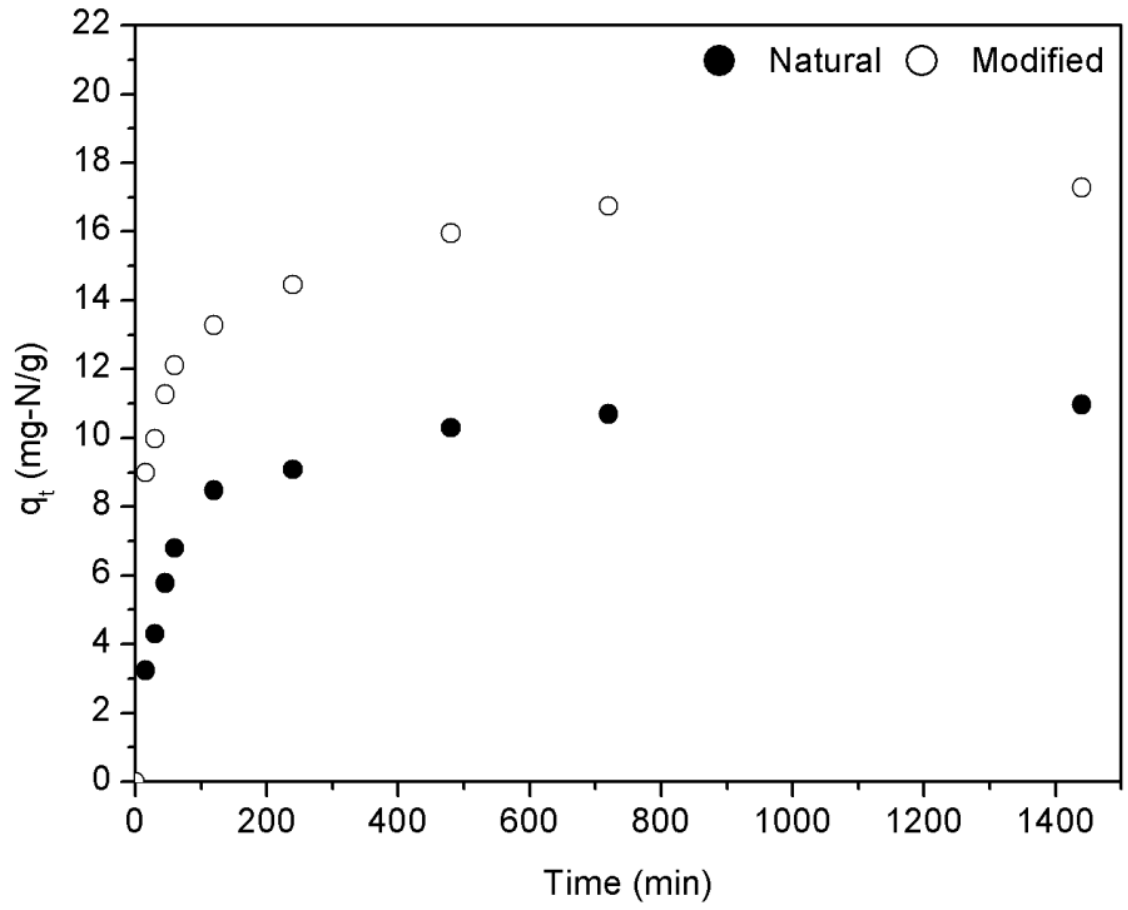

Fig. 6(a)

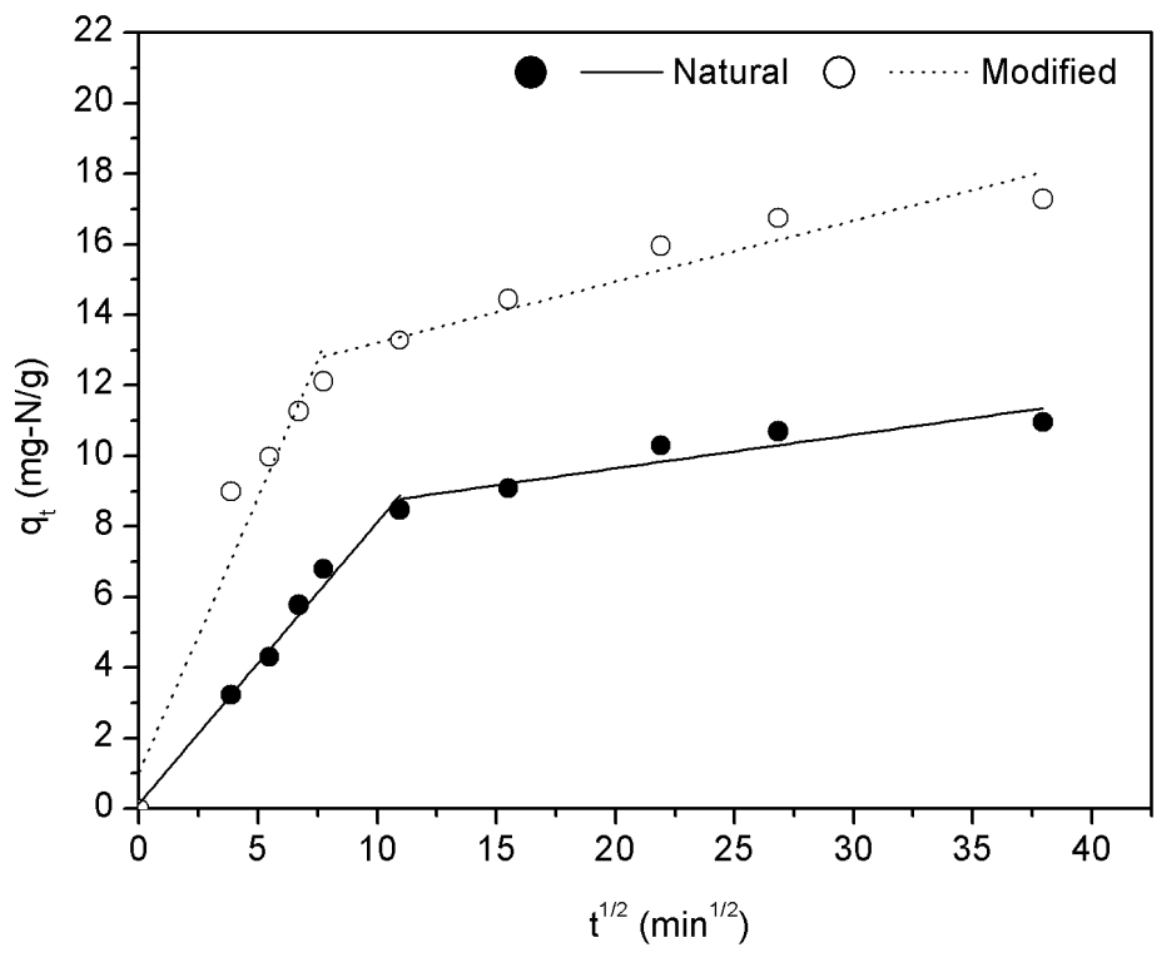

Fig. 6(b) 